\title{
EVALUATION OF PREVALENCE AND ETIOLOGICAL FACTORS OF TRAUMATIC DENTAL INJURY AMONG SCHOOL CHILDREN
}

\author{
Srinivas Danayakanapura Ramaiah', Sandhya Raghuramaiah², Shanthkumar H. V3
}

\author{
${ }_{1}^{1}$ Assistant Professor, Department of Dentistry, Shivamogga Institute of Medical Sciences, Rajiv Gandhi University of Health Sciences, \\ Shivamogga, Karanataka, India. \\ 2Dental Practitioner, Shivamogga Institute of Medical Sciences, Shivamogga, Karnataka, India. \\ ${ }^{3}$ Dental Practitioner, Shivamogga Institute of Medical Sciences, Shivamogga, Karnataka, India.
}

\begin{abstract}
BACKGROUND AND OBJECTIVES: Traumatic Dental Injuries (TDI) is emerging as an important dental cause of public health concern. TDI are more common among school children and the worldwide research clearly shows that the prevalence of TDI is increasing. Proper approach to the management requires knowledge about the extent, distribution and associated risk factors of this specific condition. So, the study was done to assess the prevalence, etiological and risk factors associated with TDI among school children in Shivamogga city, Karnataka, India.
\end{abstract}

MATERIALS AND METHODS: An epidemiological cross-sectional study was carried out among 1450 school children aged between 9-14 years in Shivamogga city. Data was collected through WHO oral health survey form and clinical examination was done to record gender, age, number of teeth injured, lip coverage, maxillary overjet and pattern of teeth injury. Collected data was analyzed using Microsoft excel and SPSS software.

RESULTS: The prevalence of TDI in the present study is found to be $12.83 \%$. The boys experienced more injury (1.48 times) than girls. Inadequate lip coverage children had more dental injuries. Children with overjet $>3.5 \mathrm{~mm}$ were more prone to TDI (4.54 times). Maxillary central incisors were commonly injured involving enamel fracture. Major cause of TDI was fall.

CONCLUSION: The prevalence of TDI in Shivamogga city is high and there is a need to create awareness among general public regarding prevention and available treatment options.

KEYWORDS: Traumatic Dental Injury, Lip Coverage, Maxillary Overjet, Teeth Fracture.

HOW TO CITE THIS ARTICLE: Srinivas Danayakanapura Ramaiah, Sandhya Raghuramaiah, Shanthkumar. H. V. "Evaluation of Prevalence and Etiological Factors of Traumatic Dental Injury among School Children”. Journal of Evolution of Medical and Dental Sciences 2015; Vol. 4, Issue 89, November 05; Page: 15455-15458, DOI: 10.14260/jemds/2015/2208.

INTRODUCTION: Traumatic dental injuries (TDI) are a significant problem in school children and has become a serious dental public health problem in developing and developed countries. ${ }^{1}$ Despite high prevalence of dental trauma, less attention has been given to TDI, its etiology and prevention. ${ }^{2}$ Review of earlier literature shows that various causes for TDI which include fall, collision, sports injury, road traffic accidents, violence and also child abuse.1,2 Increased maxillary overjet with protrusion and inadequate lip coverage are implicated as important intrinsic risk factors for TDI. It has also been observed that anterior teeth are more commonly involved in TDI.3,4

MATERIALS AND METHODS: A cross sectional study was carried out among 1450 school children ( 800 boys and 650 girls) aged between 9 and 14 years in a randomly selected schools in Shivamogga city, Karnataka, India. The study was approved by the Institutional Ethical Committee. The examinations were conducted under daylight using the WHO classification of tooth fractures.

Financial or Other, Competing Interest: None.

Submission 08-10-2015, Peer Review 09-10-2015,

Acceptance 21-10-2015, Published 05-11-2015.

Corresponding Author:

Dr. Srinivas Danayakanapura Ramaiah,

No. 21, $1^{\text {st }}$ Cross, $5^{\text {th }}$ Block, Veeranna Layout,

Vinobanagara

Shivamogga-577204, Karnataka.

E-mail: drsrinivas.trish@gmail.com

DOI: $10.14260 /$ jemds $/ 2015 / 2208$.
The criteria and scoring for TDI included, enamel fracture, enamel and dentine fracture, fracture with pulpal involvement, non-vital tooth with discoloration, displacement, missing and restored tooth with a positive history of trauma. Root fractures were not considered in the study, since no radiographs were taken.

Before the commencement of intraoral examination lip coverage of upper incisors were observed in resting position without the awareness of the child. Lip coverage was considered inadequate if the lip failed to cover upper incisors with major part of crown exposed. Over jet was measured in centric occlusion. The distance from the labioincisal edge of the most prominent maxillary incisor to the labial surface of the corresponding mandibular incisor was measured. The over jet observations were divided into two groups $<3.5 \mathrm{~mm}$ and $>3.5$ $\mathrm{mm}$. The collected data was analysed using Microsoft Excel and SPSS software.

OBSERVATIONS AND RESULTS: A total of 1450 children [800 boys $(55.17 \%)$ and 650 girls (44.83\%)] were examined and it was seen that $186(12.83 \%)$ children sustained traumatic injuries to anterior teeth. The boys were 1.48 times more prone to injuries than girls (OR=1.48 95\% CI (1.08-2.04)) which is statistically significant, $\mathrm{p}$ value 0.015 , (Table -1 ). Children with overjet $>3.5 \mathrm{~mm}$ were 4.54 times more prone to injuries as compared to children with overjet $<3.5 \mathrm{~mm}(\mathrm{OR}=4.5495 \% \mathrm{CI}$ (3.07-6.72)) which is statistically significant, $p$ value $<0.001$. Similarly children with inadequate lip coverage 
were 5.64 times more prone to injuries as compared to children with adequate lip coverage (OR=5.64 95\% CI (4.017.93)) which is statistically significant, $p$ value $<0.001$, (Table 2)

DISCUSSION:For this study children between 9 and 14 years of age were chosen, as during this period there is maximum physiologic growth and development and children are actively involved in lot of outdoor activities. The prevalence of traumatic injuries in this study was $12.83 \%$ which is in accordance with the study conducted by Adekoya sofowara etal $^{5}(12.8 \%)$. The prevalence noted in our study is higher as compared to the earlier studies done by Rambharos RR etal. ${ }^{1}(10.5 \%)$, Gauba. ${ }^{6}$ (7.5\%), Nick Hussein. ${ }^{7}$ (4.1\%).

But the higher prevalence has been observed in studies conducted by Ravi Shankar etal. ${ }^{8}$ (15.1\%) in Davangere, which is an adjacent district to Shivamogga city, $18.25 \%$ was observed in study by Ahlawat B etal. ${ }^{2}$ A significantly higher prevalence of $24 \%$ was found by Kahabuka and Mugonzibwa. ${ }^{9} 34 \%$ by Blinkhorn. ${ }^{10}$ in England, $43.8 \%$ in Newham, London, UK by Marcenesand Murry. ${ }^{11}$

The prevalence of dental trauma in various epidemiological studies has been found to differ considerably. The great variation might be due to number of factors, such as the trauma classification used, dentition status, geographical and behavioural differences between locations and countries. ${ }^{12}$

Increased overjet is considered a risk factor for TDI in school children. Study conducted by Hamdan and Rock ${ }^{13}$ have reported that children with an overjet $>5.0 \mathrm{~mm}$ were 1.37 times more likely to have a dental trauma than children with an overjet size equal or lower. Rambharos RR etal ${ }^{1}$, found that children with an overjet $>5.0 \mathrm{~mm}$ were 1.65 times more likely to have a dental trauma.

A study by MC Patel etal ${ }^{14}$ showed children having overjet more than $3.5 \mathrm{~mm}$ were 3.5 times more likely to have a dental trauma. However, in the current study children with an overjet $>3.5 \mathrm{~mm}$ were 4.54 times more likely to have a dental trauma when compared to children with overjet $<3.55 \mathrm{~mm}$, which is statistically significant (OR=4.54 95\% CI (3.07-6.72)).

There is a positive relationship between inadequate lip coverage and prevalence of TDI. The children with inadequate lip coverage were 1.62 times more likely to have dental trauma, as according to Rambharos RR etal. ${ }^{1}$ But in a study by MC Patel et al children with inadequate lip coverage were 5.4 times more prone to injuries as compared to children with adequate lip coverage. ${ }^{14}$ In this study it was found to be 5.64 times, which is statistically significant (OR=5.64 95\% CI (4.01-7.93)).

Study revealed Maxillary central incisors are the most prone teeth to dental injury and enamel fracture the most common type of fracture. ${ }^{7}$ Causes of injury can vary according to age, sex and socioeconomic status of the children. In our study the most common cause of TDI was fall, which is in accordance with earlier studies. ${ }^{15,16} \mathrm{~A}$ more recent study result identified play ground or sports related accidents as the most common cause for TDIs. ${ }^{17}$ Only $4.25 \%$ of the cases of traumatized teeth had undergone treatment. Children who suffered enamel or dentine fracture without symptoms frequently received no treatment.
Lack of adequate knowledge and proper motivation compounded by limitations imposed due to socio-economic constraints could explain the high percentage of untreated injuries.

CONCLUSION: TDIs are the most neglected oral health aspect in children. There is an increasing prevalence of TDIs Worldwide. An effort can be made to reduce the,

\section{Prevalence of TDIs by following Measures:}

1. Educational programs to children, parents and teachers regarding preventive and treatment aspects.

2. Correction of predisposing factors in the form of orthodontic treatment.

3. Use of intraoral and extraoral devices which protects teeth during sports activities.

\section{REFERENCES:}

1. Rambharos RR, Kalaskar AR, Wankhade RM, Mehta JD, Evaluation of prevalence, etiological and risk factors of traumatic dental injury in 12-14 years old school going children of central India : SRM J Res Dent Sci 2014; 5:73-7.

2. Ahlawat B, Kaur A, Thakur G, Mohindroo A. Anterior tooth trauma: A most neglected oral health aspect in adolescents. Indian J Oral Sci 2013:4;1;31-37.

3. Govindarajan M, Reddy VN, Ramalingam K, Durai KS, Rao PA, Prabhu A. Prevalence of traumatic dental injuries to the anterior teeth among 3-13 years old school children of Tamil Nadu. Contemporary Clinical Dentistry. 2012:3;2;164-167.

4. Caldas JR AF, Burgos ME. A retrospective study of traumatic dental injuries in a Brazilian dental trauma clinic. Dent traumatol 2001; 17:250-3.

5. Adekoya - sofowora CA, Adesina OA, Nasir WO, Oginni AO, Ugboko VI. Prevalence and causes of fractured permanent incisors in 12 years old Suburban Nigerian School children. Dent traumatol, 2009; 25:314-7.

6. Gauba ML. A correction of fractured anterior teeth to their proclination. JIDA 1967; 12:105-12.

7. Nick-Hussein NN. Traumatic injuries to anterior teeth among school children in Malaysia. Dent traumatol 2001; 17:149-52.

8. Ravishankar TL, Kumar MA, Ramesh N, Chaitra TR. Prevalence of traumatic dental injuries to permanent incisors among 12 year old school children in Davangere South India. Chin J Dent Res 2010:13:57-60.

9. Kahabuka FK, Mugonzibwa EA. Risk factors for injuries to maxillary permanent incisors and upper lip among school children in Dares Salaam, Tanzania. Int J Paediatr Dent 2009; 19:148-54.

10. Blinkhorn FA. The aetiology of dentoalveolar injuries and factors influencing attendance for emergency care of adolescents in the north west of England. Endod Dent Traumatol 2000:16:162-5.

11. Marcenes W, Murray S. Changes in prevalence and treatment need for traumatic dental injuries among 14 years old children in Newham, London: A deprived area. Community Dental Health 2002: 19:104-8. 
12. Bastone EB, Freer TJ, Mc Namara JR. Epidemiology of dental trauma: A review of the literature. Aust Dent J 2000; 45:2-9.

13. Hamdan MA, Rock WP. A study comparing the prevalence and distribution of traumatic dental injuries among 10-12 years old children in an urban and rural area of Jordan. Int J paediatr Dent 1995:5:237-41.

14. MC Patel, SG Sujan, The prevalence of traumatic dental injuries to permanent anterior teeth and its relation with predisposing risk factors among 8-13 years school children of Vododara city : An epidemiological study, Journal of Indian Society of Pedodontics and preventive Dentistry, Vol. 30, No. 2, 2012151-157.
15. Gupta K, Tandon S, Prabhu D. Traumatic injuries to the incisors in children of south Kanara district. A prevalence study. J Indian Soc Pedod prev Dent 2002;20:107-13.

16. Baldava P, Anup N. Risk factors for traumatic dental injuries in an adolescent male population in India. J Contemp Dent Pract 2007;8:35-42.

17. Sabuncuoglu 0. Traumatic dental injuries and attention deficit/ hyperactivity disorder: Is there a link? Dent Traumatol 2007;23:137-42.

\begin{tabular}{|c|c|c|c|}
\hline Gender & Number of Children\% & With TDI & \multirow{2}{*}{ P. 0.015} \\
\hline Boys & $800[55.17 \%]$ & $118[14.75 \%]$ & \\
\hline Girls & $650[44.83 \%]$ & $68[10.46 \%]$ & \\
\hline Total & 1450 & 186 & \\
\hline \multicolumn{3}{|c|}{ Table 1: Prevalence of TDI by Gender } \\
\hline
\end{tabular}

\begin{tabular}{|c|c|c|c|c|}
\hline \multirow{2}{*}{$\begin{array}{l}\text { Clinical } \\
\text { Condition }\end{array}$} & \multirow{2}{*}{ Number } & \multicolumn{2}{|c|}{ TDI } & \multirow{2}{*}{\begin{tabular}{|c} 
Test applied \\
chisquare \\
test
\end{tabular}} \\
\hline & & No injury & $\begin{array}{c}\text { Presence of } \\
\text { injury }\end{array}$ & \\
\hline $\begin{array}{l}\text { Overjet } \\
\text { a. } \quad<3.5 \mathrm{~mm} \\
\text { b. } \quad>3.5 \mathrm{~mm}\end{array}$ & $\begin{array}{c}1312 \\
138\end{array}$ & $\begin{array}{c}1174[89.48 \%] \\
90[65.21 \%]\end{array}$ & $\begin{array}{c}138[10.51 \%] \\
48[34.78 \%]\end{array}$ & \multirow[t]{2}{*}{$P:<0.001$} \\
\hline \multicolumn{4}{|l|}{ Lip Coverage } & \\
\hline $\begin{array}{l}\text { a. Adequate } \\
\text { b. Inadequate }\end{array}$ & $\begin{array}{c}1236 \\
214\end{array}$ & $\begin{array}{c}1126[91.10 \%] \\
138[64.49 \%]\end{array}$ & $\begin{array}{l}110[8.90 \%] \\
76[35.51 \%]\end{array}$ & $P:<0.001$ \\
\hline Table II: Assoc & FT & Mavilla & int and in & erage \\
\hline
\end{tabular}

\begin{tabular}{|c|c|c|c|c|c|c|c|c|c|c|c|c|c|}
\hline \multirow[t]{2}{*}{ Types } & \multicolumn{2}{|c|}{$\begin{array}{c}\text { Maxillary } \\
\text { central } \\
\text { incisors } \\
(11,21)\end{array}$} & \multicolumn{2}{|c|}{$\begin{array}{c}\text { Maxillary } \\
\text { lateral } \\
\text { incisors } \\
(12,22)\end{array}$} & \multicolumn{2}{|c|}{$\begin{array}{c}\text { Maxillary } \\
\text { canines } \\
(13,23)\end{array}$} & \multicolumn{2}{|c|}{$\begin{array}{c}\text { Mandibular } \\
\text { central } \\
\text { incisors } \\
(\mathbf{3 1}, \mathbf{4 1 )} \\
\end{array}$} & \multicolumn{2}{|c|}{$\begin{array}{c}\text { Mandibular } \\
\text { lateral } \\
\text { incisors } \\
(32,42) \\
\end{array}$} & \multicolumn{2}{|c|}{$\begin{array}{c}\text { Mandibular } \\
\text { canines } \\
(33,43)\end{array}$} & \multirow{2}{*}{$\begin{array}{c}\text { Total No. } \\
\& \% \\
\\
126 \\
(63.32 \%) \\
\end{array}$} \\
\hline & Boys & Girls & Boys & Girls & Boys & Girls & Boys & Girls & Boys & Girls & Boys & Girls & \\
\hline 1. Enamel & 40 & 34 & 18 & 11 & 5 & 2 & 7 & 2 & 3 & 2 & 1 & 1 & $\begin{array}{c}39 \\
(19.60 \%)\end{array}$ \\
\hline 2.Enamel/dentine & 15 & 6 & 6 & 4 & 3 & 1 & 0 & 1 & 1 & 1 & 0 & 1 & $\begin{array}{c}14 \\
(7.04 \%)\end{array}$ \\
\hline $\begin{array}{l}\text { 3. Pulpal } \\
\text { Involvement }\end{array}$ & 6 & 1 & 2 & 2 & 0 & 0 & 1 & 0 & 2 & 0 & 0 & 0 & $\begin{array}{c}12 \\
(6.03 \%)\end{array}$ \\
\hline 4. Non-vital & 5 & 2 & 2 & 1 & 0 & 0 & 1 & 0 & 0 & 0 & 1 & 0 & $\begin{array}{c}3 \\
(1.51 \%)\end{array}$ \\
\hline 5. Displacement & 1 & 1 & 0 & 0 & 0 & 1 & 0 & 0 & 0 & 0 & 0 & 0 & $\begin{array}{c}5 \\
(2.51 \%)\end{array}$ \\
\hline 6. Avulsion & 1 & 0 & 0 & 0 & 3 & 1 & 0 & 0 & 0 & 0 & 0 & 0 & $\begin{array}{c}199 \\
(100 \%)\end{array}$ \\
\hline \multirow[t]{2}{*}{ Total } & 68 & 44 & 28 & 18 & 11 & 5 & 9 & 3 & 6 & 3 & 2 & 2 & $\begin{array}{c}199 \\
(100 \%)\end{array}$ \\
\hline & \multicolumn{2}{|c|}{ 112(56.28\%) } & \multicolumn{2}{|c|}{$46(23.12 \%)$} & \multicolumn{2}{|c|}{$16(8.04 \%)$} & \multicolumn{2}{|c|}{$12(6.03 \%)$} & \multicolumn{2}{|c|}{$09(4.52 \%)$} & \multicolumn{2}{|c|}{$4(2.01 \%)$} & \\
\hline & & Tabl & $D i$ & utio & 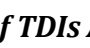 & cord & 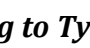 & e of I & yan & ooth & & & \\
\hline
\end{tabular}




\begin{tabular}{|c|c|c|c|}
\hline \multirow{2}{*}{ Cause } & \multicolumn{2}{|c|}{ Number of Children } & \multirow{2}{*}{ Percentage } \\
\cline { 2 - 4 } & Boys & Girls & $46.24 \%$ \\
\hline Fall & 52 & 34 & $24.19 \%$ \\
\hline Sports & 34 & 11 & $11.83 \%$ \\
\hline Accident & 14 & 8 & $6.99 \%$ \\
\hline Violence & 10 & 3 & $5.91 \%$ \\
\hline Biting trauma & 5 & 6 & $4.84 \%$ \\
\hline Unknown & 3 & 6 & $\mathbf{1 0 0 \%}$ \\
\hline Total & $\mathbf{1 1 8}$ & $\mathbf{6 8}$ & \\
\hline \multicolumn{4}{|c}{ Table: IV: Distribution of TDI by Etiology } \\
\hline
\end{tabular}

